Boom juridisch

Postbus 85576

2508 CG Den Haag

T (070) 3307033

E info@bju.nl

www.boomjuridisch.nl

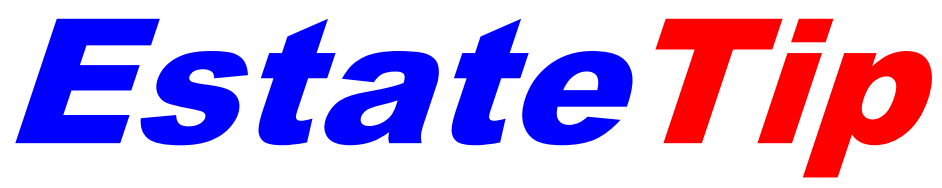

\title{
Vruchtgebruik-ruzies, voorkomen is beter dan genezen of straffen
}

Vruchtgebruikregelingen worden regelmatig ingezet. Vaak om fiscale redenen, in welk geval in de regel gewerkt wordt met een vruchtgebruik met vervreemdings- en verteringsbevoegdheid (art. 3:212 BW jo. 3:215 BW). Maar soms ook om vermogen in de familie te houden. In een dergelijk geval zal, in ieder geval, de verteringsbevoegdheid ontbreken. De spanning is vaak te snijden tussen de bloot eigenaren en de vruchtgebruikers. En het gaat ook regelmatig fout. Van jurisprudentie in dit kader kunnen we veel leren, zo ook van Rechtbank Midden-Nederland 20 maart 2019, ECLI:NL:RBMNE:2019:1088. De langstlevende partner was vruchtgebruiker, de kinderen van de erflater en de kinderen van de langstlevende partner waren erfgenamen. Op zich al explosief. En er was dan ook herrie. Per saldo werd er van de rechter gevraagd het vruchtgebruik van de partner te beëindigen. Er zou, zo vat ik het maar even samen, door de vruchtgebruiker vermogen ten onrechte onttrokken zijn. Kan de rechter het vruchtgebruik als strafsanctie beëindigen? De rechtbank duikt in de parlementaire geschiedenis van titel 3.8. BW in het bijzonder rondom artikel 3:321 BW:

'Enige leden hebben bepleit naast de regeling van lid 1 een verder gaande sanctie mogelijk te maken, in die zin dat de vruchtgebruiker bij grof verzuim of ernstige verwaarlozing van de goederen waarop het recht gevestigd is, wordt gestraft met vervallenverklaring van zijn recht. De ondergetekende is van oordeel dat Meijers in navolging van het Ontwerp 1898 deze mogelijkheid terecht niet uit de artikelen 862 en 863 B.W. en 618 Cc. heeft overgenomen. De praktijk heeft geleerd dat zij vrijwel geen toepassing vindt. Het burgerlijk recht onthoudt zich ook elders van civiele straffen, wanneer bescherming van de belangen die door misdragingen worden geschaad, op andere wijze voldoende verzekerd kan worden. Dit is hier het geval. Dat ontneming van het beheer de vruchtgebruiker onder omstandigheden als verlossing van de daaraan verbonden beslommeringen niet onwelgevallig kan zijn, zodat deze dreiging hem van misbruik niet zou weerhouden, acht de ondergetekende niet overtuigend. De vruchtgebruiker blijft tot vergoeding van de aangerichte schade gehouden (zie Parl. Gesch. Boek 3 BW, MvA II, p. 675).'

Geen vervallenverklaringsmogelijkheden, maar wel de mogelijkheid van artikel 3:221 waarin is bepaald dat indien de vruchtgebruiker in ernstige mate tekortschiet in de nakoming van zijn verplichtingen, de rechtbank op vordering van de hoofdgerechtigde aan 
deze het beheer kan toekennen of het vruchtgebruik onder bewind kan stellen. Een wat lichtere sanctie. Deze was evenwel niet gevorderd, ofwel in de woorden van de rechtbank:

'Nu de wet zoals gezegd geen mogelijkheid biedt voor een vervallenverklaring van het vruchtgebruik, zal de daarop gerichte vordering in conventie van [eiser] worden afgewezen. Ook de door [eiser] genoemde "redelijkheid en billijkheid" bieden op zichzelf geen grondslag voor vervallenverklaring van het zakelijk recht van vruchtgebruik van [gedaagde sub 1]. Dit brengt tevens mee dat de vraag of [gedaagde sub 1] in ernstige mate is tekortgeschoten in haar verplichtingen als vruchtgebruiker in de zin van art. 3:221 lid $1 \mathrm{BW}$ - zoals [eiser] stelt en [gedaagde sub 1] betwist - in dit geding geen beantwoording behoeft. Immers, ook indien daarvan sprake is, kan dit niet leiden tot de door [eiser] gevorderde verdeling en beëindiging van het vruchtgebruik.'

Deze uitspraak doet mij overigens denken aan de uitspraak van Hof Den Bosch 27 december 2016, ECLI:NL:GHSHE:2016:5654 (ERF-Updates 2017-0017) en EstateTip Review 2017-7. Daar was er gedoe over de vraag wie welke kosten draagt. Ook in die zaak merkt het hof op dat vervallenverklaring van het zakelijk recht van gebruik en bewoning/vruchtgebruik sinds de invoering van het nieuw Burgerlijk Wetboek niet meer mogelijk is.

Wat leren we van deze zaken? Op de eerste plaats worden we weer alert gemaakt op het vruchtgebruik als bron van conflicten. Is een vruchtgebruikconstructie gewenst - hetzelfde geldt overigens ook voor een tweetrapsregeling - dan moet de estate planner er even voor gaan zitten en het regime goed uitwerken. Wie mag wat? Wie betaalt wat? Maar het stellen van de vraag 'wie controleert?' is ook niet gek. Ik kom hier zo op terug. We worden ook weer, en dat is het tweede aandachtspunt, herinnerd aan het vruchtgebruikbewind van artikel 3:321 BW: een noodverband als het fout gaat. Maar waarom pas achteraf optreden en niet al meteen met een scheidsrechter werken door middel van een conflictbewind? In EstateTip Review 2017-7 werd de conflictbewindvoerder omschreven als een functionaris die vanaf den beginne meekijkt, meebeschrijft en oordeelt over vraag- en geschilpunten, een scheidsrechter en administrateur. Het betreft een Boek-4 bewindvoerder 'in het belang van de ander dan de rechthebbende' wiens taak op maat kan worden ingekleurd met artikel 4:171 BW. Deze figuur wordt veel te weinig toegepast. De uitspraak van Rechtbank Midden-Nederland geeft mij de gelegenheid om nogmaals voor deze figuur te pleiten. Zie voor meer het KNB-preadvies van F.W.J.M. Schols, 'Bewind en aan bewind verwante vormen': theoretische en praktische varia, Vermande 2005, p. 55 e.v. en A.G. Lubbers, Bewind in het NBW, studiepockets privaatrecht, nr. 29, Tjeenk-Willink 1983, p. 119.

Het derde punt van aandacht is de vervallenverklaring. Dat bloot eigenaren behoefte hebben om via een vervallenverklaring de vruchtgebruiker te elimineren is evident. De vraag is natuurlijk of de testateur deze sanctie gewenst vindt. De testamentaire last opgelegd op erfgenamen om hen te bewegen tot afgifte van het vruchtgebruiklegaat zien we regelmatig. Een extra stok achter de deur. Een onafhankelijke executeur vormt evenwel in de regel voldoende smeerolie om tot een soepele afgifte te komen. Maar de vraag is of de testateur ook een sanctie wil om een tekortschietende vruchtgebruiker keihard te straffen. In voorkomende gevallen zal men dat gewenst vinden. Men heeft dan de keuze om te werken met een vruchtgebruik onder (zelf in elkaar geknutselde) ontbindende voorwaarde of een door de wetgever voorgevormde testamentaire last. Het voordeel van de testamentaire last is dat de rechter er tussen zit, die de (te) harde kantjes van een strafsanctie kan halen. Van welke variant ook gebruik wordt gemaakt, in beide 
gevallen geldt dat de overtredingen die het einde van het vruchtgebruik betekenen, de delictsomschrijvingen, helder omschreven dienen te worden.

Geniet, maar gebruik met mate. De conflictbewindvoerder geniet mijn voorkeur.

\section{Tot volgende week!}

Prof. mr. dr. F.W.J.M. Schols

ScholsBurgerhartSchols

\section{Boomjuridisch}

www.scholsburgerhartschols.nl www.boomjuridisch.nl

(C) 2019 Boom juridisch | ScholsBurgerhartSchols

Hoewel de uiterste zorg is besteed aan de inhoud van EstateTip Review aanvaarden de uitgever en de redactie geen aansprakelijkheid voor onvolledigheid of onjuistheid. 